\title{
Total lipids and fatty acid profile in the liver of wild and farmed catla catla fish
}

\author{
By Muhammad Hassan, ${ }^{1}$ Shahzad Ali Shahid Chatha, ${ }^{{ }^{2}}$ Ismat Tahira ${ }^{1}$ and Bilal Hussain ${ }^{3}$
}

\author{
1'Department of Zoology, GC University, Faisalabad, Pakistan. \\ ${ }^{2}$ Department of Chemistry, GC University, Faisalabad, Pakistan. \\ ${ }^{3}$ Department of Bioinformatics, GC University, Faisalabad, Pakistan \\ ( ${ }^{\star}$ Corresponding author: saschatha@gcuf.edu.pk)
}

\begin{abstract}
RESUMEN
Lípidos totales y perfil de ácidos grasos de hígado de pescado catla catla salvajes y criados
\end{abstract}

Este trabajo experimental tiene como objetivo estudiar el contenido de humedad, lípidos totales y perfil de ácidos grasos de hígado de carpa de agua dulce Catla catla de tres categorías con peso diferentes designadas como $\mathrm{W}_{1}$ (601$900 \mathrm{~g}), \mathrm{W}_{2}(901-1200) \mathrm{g}$ and $\mathrm{W}_{3}(1201-1500 \mathrm{~g})$. Siete muestras de pescados por cada una de las tres categorías de peso para Catla catla salvajes y criados fueron obtenidos de Trimu Head, Jhang and Fish Hatchery, Satiana Road y Faisalabad, respectivamente. Los pescados fueron diseccionados para obtener el hígado y las muestras de hígado fueron preparadas y sujetas a análisis químico. Catla catla salvaje tuvo un contenido de humedad significativamente mayor $(p<0.05)$ en comparación con las especies criadas. En Catla catla criadas se depositaron mayores contenidos de lípidos en el hígado. La proporción de ácidos grasos saturados vario irregularmente en los lípidos del hígado de Catla catla salvajes y criados. Los ácidos grasos saturados C12:0, C14:0, C16:0, C18:0, C20:0 y C22:0 fueron identificados en un alto porcentaje en hígados de Catla catla procedentes de ambos hábitat y el ácido graso monoinsaturado C18:1 fue encontrado en una cantidad considerable en el hígado de ambas carpas. Los ácidos grasos poliinsaturados tales como C18:3 (n-6) y C20: 2 (n-6) fueron detectados en el hígado de pescados salvajes $W_{2}$ y $W_{3}$, así como en la misma categoría de peso $W_{3}$ de especies criadas.

PALABAS CLAVE: Ácidos grasos poliinsaturados - Ácidos grasos saturados - Catla catla salvaje - Catla catla criado-Categoría por peso - Hígado - Humedad - Lípidos.

\section{SUMMARY}

Total lipids and fatty acid profile in the liver of wild and farmed catla catla fish

This experimental work was aimed to study the moisture content, total lipids and fatty acid profile in the liver of wild and farmed freshwater major carp Catla catla of three different weight categories designated as $W_{1}$ (601-900g), $W_{2}$ (901$1200) g$ and $W_{3}(1201-1500 g)$. Seven fish specimens of each of the three weight categories of wild and farmed Catla catla were obtained from Trimu Head, Jhang and Fish Hatchery, Satiana Road and Faisalabad, respectively. The fish were dissected to remove the liver and after weighing, liver samples were prepared and subjected to chemical analysis. Wild Catla catla liver had a significantly $(p<0.05)$ higher moisture content as compared to the farmed species. Farmed Catla catla deposited significantly $(p<0.05)$ higher lipid contents in liver. Proportions of saturated fatty acids varied irregularly in the lipids of the liver from both wild and farmed Catla catla. Saturated fatty acids C12:0, C14:0, C16:0, C18:0, C20:0 and C22:0 were identified with considerable percentages in the liver of Catla catla from both habitats and monounsaturated fatty acid C18:1 was found in considerable amounts in the liver of both major carp. Polyunsaturated fatty acids such as C18:3 (n-6) and C20: 2 (n-6) were detected in the liver of the wild fish of $W_{2}$ and $W_{3}$ and was similar in the $W_{3}$ weight category of the farmed species.

KEY-WORDS: Catla catla farmed - Catla catla wild - Lipids - Liver - Moisture - Polyunsaturated fatty acids Saturated fatty acids - Weight category.

\section{INTRODUCTION}

Fish has been recognized as an excellent food source for human beings for centuries and is preferred as a perfect diet not only due to its excellent taste and high digestibility but also because of having higher proportions of unsaturated fatty acids, essential amino acids and minerals for the formation of functional and structural proteins (Anonymous, 2003; Kumar, 1992). Fish oil contains essential fatty acids, essential to the maintenance of cell membrane structure throughout the body and people who consume more fish containing $n-3$ fatty acids consistently have lower incidence of heart disease (Kromhout et al., 1985). Lipids are generally regarded as the most important constituent that determine the quality of fish meat (Caulton and Bursell, 1977; Love et al., 1984). The total lipid and ash contents of fish are reported to vary significantly with gradual increase in the weight and length of the fish and also due to seasonal changes aside from the available nutrients in varied habitats. Similar comparisons regarding the percent fat and ash contents of Oreochromis niloticus can be found in literature reports (Al-Asgah, 1992). Literature reports reveal that the lipid contents in the liver of Sciaenops ocellatus varied from $7.4-30.2 \%$ of wet weight from November to August (Craig et al., 2000). Selected marine fish in Malaysian waters are reported to contain less than $6 \%$ lipids, $37.1-49.1 \%$ cholesterol, $29.7-48.4 \%$ n-3 polyunsaturated fatty acids and $3.63-11.4 \%$ saturated fatty acids (Osman et al., 2001). 
A number of literature reports are available regarding the lipid contents of the palatable parts of fish but the comprehensive information pertaining to fatty acid profile of the liver and other visceral organs of indigenous major exotic carps is scarce. Liver and other visceral organs are taken out and discarded during the dressing of fish and this could mean the loss of important biochemical compounds of vital importance to the animal feed industry. The present work was aimed to compare the lipid contents and fatty acid profile of the liver from both wild and farmed Catla catla fish of three different weight categories so that the information about lipids and fatty acid profile of the liver of Catla catla fish could be useful for food technologists in feed formulations for livestock. In addition, the liver of the Catla catla fish could be a vital source of some fatty acids to maintain human health.

\section{MATERIALS AND METHODS}

Freshwater major carp Catla catla (Thela), from both wild and farmed habitats, were analyzed for the estimation of total lipids and fatty acid profile of its liver.

\subsection{Source of fish}

A total of 21 wild Catla catla fish of three different weight categories designated as $\mathrm{W}_{1}(601-900 \mathrm{~g}), \mathrm{W}_{2}$ (901-1200g) and $\mathrm{W}_{3}(1201-1500 \mathrm{~g})$ were captured with the help of gill net, during non-spawning season, from Trimu Head, Jhang (95 km away from Faisalabad) and transported live to Fisheries Research Laboratory, Department of Zoology, GC University, Faisalabad. Similarly, 21 farmed Catla catla fish of three different weight categories $W_{1}, W_{2}$ and $W_{3}$ were obtained during non-spawning period from the fish Hatchery, Satiana Road, Faisalabad and transported live to the Fisheries Research Laboratory, Department of Zoology, GC University, Faisalabad.

\subsection{Preparation of fish samples for analysis}

All the fish specimens were rinsed out in running dechlorinated tap water for two days, thereby facilitating the emptying and removal of stomach contents. Later on, the fish were sterilized, blotted dry with paper towels and then weighed on an electric balance. Each fish was given a vertical cut from the ventral side and the liver was taken out of the dissected fish.

\subsection{Estimation of moisture and lipid contents}

Each sample of liver was minced and immediately oven-dried $\left(65^{\circ}-70^{\circ} \mathrm{C}\right)$ for 24 hours. The dried sample was weighed on an electric balance and the moisture content of each sample was calculated by standard method (AOAC, 1990). The total lipid contents of each pre-weighed duplicated sample were extracted using a Soxhlet apparatus and $\mathrm{n}$-hexane as solvent. Each sample was made moisture free with $\mathrm{Na}_{2} \mathrm{SO}_{4}$. The solvent was distilled off under reduced pressure using a rotary evaporator (EYELA, Rotary Vacuum Evaporator, N.N. Series, equipped with an Aspirator and a Digital Water Bath SB-651, Japan) according to the standard method and stored under refrigeration $\left(4^{\circ} \mathrm{C}\right)$ until used for further analysis (Perumal and Becker, 2003; AOAC, 1990).

\subsection{Fatty acid analysis}

Fatty acid methyl esters (FAME) of each lipid sample were prepared according to the standard method described by the Association of Official Analytical Chemists (AOAC, 1990). FAME were separated, identified and quantified by gas liquid chromatography, Perkin-Elmer Model Column (glass) $39202 \mathrm{~m} \times 2 \mathrm{~mm}$ packed with $20 \%$ DEGS on chromosorb W equipped with FID detection and temperature programming at $200{ }^{\circ} \mathrm{C}$ injector, $190^{\circ} \mathrm{C}$ column and $250^{\circ} \mathrm{C}$ detector; $20 \mathrm{psi}_{2}, 50$ psi air with $0.2 \mu \mathrm{L}$ injection with $1.0 \mu \mathrm{L}$ (SGE) syringe. Individual methyl esters were identified by comparison to known standards obtained from $\mathrm{E}$. Merck and Sigma-Aldrich Chemical Co. (St. Louis, $\mathrm{MO}$ ).

\subsection{Statistical analysis}

The data obtained was analyzed using the ANOVA statistical technique by computer following the Minitab Package (SAS, 1995).

\section{RESULTS AND DISCUSSION}

An experiment was performed to study the percentage of moisture, total lipids and fatty acid profile in the liver from wild and farmed freshwater major carp, Catla catla, of three different weight categories designated as $W_{1}, W_{2}$ and $W_{3}$. The data recorded through physical and chemical analyses were subjected to a statistical analysis which showed significant variations in moisture contents, total lipids content and the deposition of fatty acids in the liver of wild and farmed freshwater major carp Catla catla under all three weight categories.

\subsection{Moisture contents}

Mean moisture contents in the liver from wild and farmed Catla catla, were recorded under three different weight categories designated as $W_{1}, W_{2}$ and $W_{3}$ (Table 1). Duncan's Multiple Range test revealed that the differences among the three weight categories of both wild and farmed Catla catla were significant $(p<0.05)$. The liver of the wild fish showed maximum moisture percentage under weight category $W_{1}$ closely followed by farmed fish of the same weight category. Regarding the overall performance, the wild Catla catla 
showed significantly $(p<0.05)$ higher moisture contents in liver as compared to that of farmed fish. It was observed that the moisture content in the liver decreased with increasing body weight of the fish as recorded for the wild as well as the farmed habitat. The statistical analysis showed that the wild Catla catla deposited significantly higher ( $p$ $<0.05$ ) water contents as compared to the farmed fish species. This increased water contents in the liver of wild Catla catla in all three weight categories were due to decreasing fats and protein contents in the fish body that may be attributed to more physical efforts performed by the wild fish species to capture food organisms in the natural habitat than the farmed fish which has plenty of food supply in the well-fertilized ponds. The findings of the present study are in close agreement with the lines reported by Srikanth et al., (1989) who described that in the flesh of Cyprinus caprio, moisture and ash contents decreased with an increase in fats and protein contents and vice versa.

\subsection{Lipid contents}

Total lipid contents in the liver from wild and farmed Catla catla are recorded under three weight categories in table 2. Duncan's Multiple Range test showed that lipid percentages among all three different weight categories of Catla catla differed significantly $(p<0.05)$. Lipids are generally regarded as the most important constituent used to evaluate the quality of fish meat (Caulton and Bursell, 1977; Love et al., 1984). In the present experiment, concentrations of lipids in the liver varied from 3.32 $\pm 0.06-5.91 \pm 0.01 \%$ in wild Catla catla and 4.72 $\pm 0.07-7.43 \pm 0.12 \%$ in the farmed fish species The lipid contents in the liver showed an increasing trend with increased body weight of the fish. The farmed Catla catla accumulated a significantly ( $p<$ 0.05 ) higher amount of lipids in the liver than the wild species and this may be attributed to differences in their feeding habits. The wild fish has to make strenuous efforts in foraging food organisms, for which more fats are consumed to supply energy and consequently, the deposition of fat in the body of the wild fish species is comparatively lower (Mahboob, 1992; Hassan, 1996). Literature reports also reveal that the lipid contents in the fish body are also affected by environmental and nutritional conditions (Polvi and Ackman, 1992). The total lipid content was found to have a direct relationship with body weight of wild and farmed Catla catla. It was noted that mean percentage values of moisture decreased in the liver with an increase of body weight both in wild and farmed Catla catla while total lipid contents increased in the liver with an increase in body weight of the fish species in both habitats. The data reflects that the moisture contents in the liver from wild and farmed Catla catla decreased with a corresponding increase in total lipid contents and vice versa.

\subsection{Fatty acid composition in liver}

In the present investigation, the fatty acid compositions determined by GC analysis of liver lipid from wild and farmed Catla catla have been presented in Tables 3-4. It was observed that the fatty acid composition of total lipids varied greatly in the liver under all three weight categories of wild and farmed Catla catla fish. The body weight of the fish, both from wild and farmed habitats influenced the composition of fatty acids in the liver lipid significantly $(p<0.05)$. In theses findings, no specific pattern of variations in fatty acid composition was observed in the liver of wild or farmed fish.

Table 1

Moisture contents (\%) in liver from wild and farmed Catla catla

\begin{tabular}{cccc}
\hline $\begin{array}{c}\text { Weight } \\
\text { Categories }\end{array}$ & $\begin{array}{c}\text { Wild Fish } \\
\text { (Mean } \pm \text { SE) }\end{array}$ & $\begin{array}{c}\text { Farmed Fish } \\
\text { (Mean } \pm \text { SE) }\end{array}$ & (Mean \pm SE) $^{\text {(Mean }}$ \\
\hline$W_{1}$ & $76.45 \pm 2.10^{\mathrm{a}}$ & $75.43 \pm 2.01^{\mathrm{a}}$ & $75.94 \pm 1.81^{\mathrm{a}}$ \\
$\mathrm{W}_{2}$ & $73.07 \pm 2.22^{\mathrm{b}}$ & $68.13 \pm 1.80^{\mathrm{a}}$ & $70.60 \pm 2.00^{\mathrm{b}}$ \\
$\mathrm{W}_{3}$ & $69.43 \pm 1.30^{\mathrm{c}}$ & $61.47 \pm 1.40^{\mathrm{a}}$ & $65.45 \pm 1.92^{\mathrm{a}}$ \\
Mean $\pm \mathrm{SE}$ & $72.98 \pm 1.37^{\mathrm{b}}$ & $68.34 \pm 1.51^{\mathrm{a}}$ & \\
\hline
\end{tabular}

Means with different letters in the same row are significantly different at $(p<0.05)$.

$\mathrm{SE}=$ Standard error, $\mathrm{W}_{1}(601-900 \mathrm{~g}), \mathrm{W}_{2}(901-1200 \mathrm{~g}), \mathrm{W}_{3}(1201-1500 \mathrm{~g})$.

Table 2

Total lipid contents (\%) in liver from wild and farmed Catla catla

\begin{tabular}{cccc}
\hline $\begin{array}{c}\text { Weight } \\
\text { Categories }\end{array}$ & $\begin{array}{c}\text { Wild Fish } \\
\text { (Mean } \pm \text { SE) }\end{array}$ & $\begin{array}{c}\text { Farmed Fish } \\
\text { (Mean } \pm \text { SE) }\end{array}$ & (Mean \pm SE) \\
\hline$W_{1}$ & $3.32 \pm 0.06^{\mathrm{a}}$ & $4.72 \pm 0.07^{\mathrm{c}}$ & $4.02 \pm 0.19^{\mathrm{b}}$ \\
$\mathrm{W}_{2}$ & $4.58 \pm 0.07^{\mathrm{b}}$ & $6.41 \pm 0.06^{\mathrm{c}}$ & $5.49 \pm 0.25^{\mathrm{b}}$ \\
$\mathrm{W}_{3}$ & $5.91 \pm 0.01^{\mathrm{c}}$ & $7.43 \pm 0.12^{\mathrm{c}}$ & $6.67 \pm 0.22^{\mathrm{b}}$ \\
Mean $\pm \mathrm{SE}$ & $4.60 \pm 0.24^{\mathrm{b}}$ & $6.18 \pm 0.25^{\mathrm{b}}$ & \\
\hline
\end{tabular}

Means with different letters in the same row are significantly different at $(p<0.05)$. SE $=$

Standard error, $\mathrm{W}_{1}(601-900 \mathrm{~g}), \mathrm{W}_{2}(901-1200 \mathrm{~g}), \mathrm{W}_{3}(1201-1500 \mathrm{~g})$. 
Table 3

Fatty acids profile (\%) in liver from wild Catla catla

\begin{tabular}{lccc}
\hline Fatty Acids & $\mathbf{W}_{\mathbf{1}}$ & $\mathbf{W}_{\mathbf{2}}$ & $\mathbf{W}_{\mathbf{3}}$ \\
\hline Saturated Fatty Acids & & & \\
C12:0 & $01.47 \pm 0.30^{\mathrm{a}}$ & $01.40 \pm 0.05^{\mathrm{a}}$ & $01.05 \pm 0.12^{\mathrm{a}}$ \\
C14:0 & $01.81 \pm 0.12^{\mathrm{b}}$ & $01.10 \pm 0.13^{\mathrm{a}}$ & $00.98 \pm 0.19^{\mathrm{a}}$ \\
C16:0 & $42.10 \pm 1.75^{\mathrm{a}}$ & $45.03 \pm 3.23^{\mathrm{ab}}$ & $48.50 \pm 1.64^{\mathrm{b}}$ \\
C18:0 & $02.80 \pm 0.95^{\mathrm{b}}$ & $02.20 \pm 0.38^{\mathrm{b}}$ & $01.09 \pm 0.74^{\mathrm{a}}$ \\
C20:0 & $00.76 \pm 0.07^{\mathrm{a}}$ & $00.95 \pm 0.26^{\mathrm{b}}$ & $00.95 \pm 0.08^{\mathrm{b}}$ \\
C22:0 & $00.23 \pm 0.03^{\mathrm{a}}$ & $00.80 \pm 0.03^{\mathrm{b}}$ & $01.08 \pm 0.01^{\mathrm{c}}$ \\
\hline Unsaturated Fatty Acids & & & \\
C18:1 & $26.89 \pm 0.90^{\mathrm{a}}$ & $30.50 \pm 0.98^{\mathrm{b}}$ & $30.69 \pm 1.37^{\mathrm{b}}$ \\
C18:3 & $03.49 \pm 0.28^{\mathrm{c}}$ & $02.60 \pm 0.31^{\mathrm{b}}$ & $01.89 \pm 0.15^{\mathrm{a}}$ \\
C18:3(n-6) & $00.39 \pm 0.03^{\mathrm{a}}$ & $00.87 \pm 0.08^{\mathrm{c}}$ & $00.45 \pm 0.07^{\mathrm{b}}$ \\
C20:2(n-6) & - & $00.80 \pm 0.04^{\mathrm{b}}$ & $00.50 \pm 0.03^{\mathrm{a}}$ \\
C20:5(n-3) & - & - & $00.25 \pm 0.02$ \\
C22:4(n-6) & - & - & $00.73 \pm 0.05$ \\
\hline
\end{tabular}

Values with different letters in the same row present significant differences at $(p<0.05)$.

$\mathrm{W}_{1}(601-900 \mathrm{~g}), \mathrm{W}_{2}(901-1200 \mathrm{~g}), \mathrm{W}_{3}(1201-1500 \mathrm{~g})$.

Table 4

Fatty acids profile (\%) in liver from farmed Catla catla

\begin{tabular}{lccc}
\hline \multicolumn{1}{c}{ Fatty Acids } & $\mathbf{W}_{\mathbf{1}}$ & $\mathbf{W}_{\mathbf{2}}$ & $\mathbf{W}_{\mathbf{3}}$ \\
\hline Saturated Fatty Acids & & & \\
C12:0 & $01.18 \pm 0.05^{\mathrm{a}}$ & $01.62 \pm 0.09^{\mathrm{b}}$ & $01.77 \pm 0.09^{\mathrm{b}}$ \\
C14:0 & $00.55 \pm 0.04^{\mathrm{b}}$ & $00.32 \pm 0.07^{\mathrm{a}}$ & $00.82 \pm 0.06^{\mathrm{c}}$ \\
C16:0 & $35.57 \pm 1.09^{\mathrm{a}}$ & $41.89 \pm 2.19^{\mathrm{b}}$ & $46.81 \pm 2.51^{\mathrm{c}}$ \\
C18:0 & $10.15 \pm 0.89^{\mathrm{c}}$ & $07.07 \pm 0.35^{\mathrm{b}}$ & $00.95 \pm 0.07^{\mathrm{a}}$ \\
C20:0 & $02.80 \pm 0.13^{\mathrm{a}}$ & $02.71 \pm 0.17^{\mathrm{a}}$ & $02.78 \pm 0.19^{\mathrm{a}}$ \\
C22:0 & $01.78 \pm 0.05^{\mathrm{a}}$ & $02.38 \pm 0.03^{\mathrm{b}}$ & $02.65 \pm 0.09^{\mathrm{c}}$ \\
\hline Unsaturated Fatty Acids & & & \\
C18:1 & $28.75 \pm 0.94^{\mathrm{a}}$ & $29.33 \pm 1.00^{\mathrm{a}}$ & $31.19 \pm 1.09^{\mathrm{b}}$ \\
C18:3 & $01.52 \pm 0.05^{\mathrm{b}}$ & $01.38 \pm 0.06^{\mathrm{a}}$ & $01.72 \pm 0.08^{\mathrm{c}}$ \\
C18:3(n-6) & $00.33 \pm 0.07^{\mathrm{a}}$ & $00.53 \pm 0.06^{\mathrm{b}}$ & $00.91 \pm 0.10^{\mathrm{c}}$ \\
C20:2(n-6) & - & $00.20 \pm 0.03^{\mathrm{a}}$ & $00.69 \pm 0.01^{\mathrm{b}}$ \\
C20:5(n-3) & - & - & $00.59 \pm 0.02$ \\
C22:4(n-6) & - & - & $00.79 \pm 0.11$ \\
\hline
\end{tabular}

Values with different letters in the same row present significant differences a t $(p<0.05)$.

$\mathrm{W}_{1}(601-900 \mathrm{~g}), \mathrm{W}_{2}(901-1200 \mathrm{~g}), \mathrm{W}_{3}(1201-1500 \mathrm{~g})$

It was observed that the concentrations of C12:0 and C14:0 saturated fatty acids were found to decrease with the increasing weight of fish in the farmed species, whereas this relation was found inverse in the case of the wild species. Saturated fatty acid C16:0, observed as a major constituent of liver lipid, showed an increasing trend with the increase in body weight of the fish in both habitats in a significant $(p<0.05)$ manner. The saturated fatty acids C20:0, C22:0 also showed an increasing trend with body weight while C18:0 decreased with increasing body weight in both environments, although not significantly ( $p<0.05$ ). The findings of the present experiment contradict the results declared by Tabassum (2003) who reported a higher concentration of C18:0 in the liver lipid of Cyprinus carpio. Our findings are also not in close agreement with the results reported by Saify et al., (2003) for the saturated fatty aids in the liver lipids of marine Eusphyra blochii and Carcharhinus bleekeri. These contradictions could be ascribed to differences in fish species and habitats in the present investigation.

In mono-unsaturated fatty acids, C18:1 fatty acid was observed in the highest concentration and ranged from $26.89 \pm 0.90-30.69 \pm 1.37$ and $28.75 \pm 0.94-31.19 \pm 1.09 \%$ in the liver lipids of wild and farmed Catla catla, respectively. Its concentration seemed to increase with body weight in the farmed species but not significantly $(p<0.05)$. Our findings regarding the C18:1 fatty acid are almost comparable with the concentration reported by Saify et al., (2003) for the same fatty acid in the liver lipids of marine Eusphyra blochii and Carcharhinus bleekeri.

The variations in polyunsaturated fatty acids (PUFA) were evident in the liver lipids of wild and farmed Catla catla and are presented in tables 3 
and 4. Polyunsaturated fatty acid (PUFA) C20:5 (n3) was estimated to be $0.59 \pm 0.02 \%$ in the liver of farmed and $0.25 \pm 0.02 \%$ in wild Catla catla of $\mathrm{W}_{3}$ weight category, while in other weight categories, C20:5 ( $n-3)$ remained unidentified. PUFA C18:3 $(n-6)$ was found in the liver lipids from both wild and farmed Catla catla in the range of 0.39-0.45 and $0.33-0.91 \%$, respectively. Its increasing trend in concentration was regular with increasing body weight in the liver lipid of farmed Catla catla but irregular in the other habitat. PUFA C20:2 (n-6) was observed in the $\mathrm{W}_{2}$ and $\mathrm{W}_{3}$ weight categories in both habitats of Catla catla fish whereas C22:4 $(n-6)$ was observed in $W_{3}$ category only. Overall, the identified PUFA were found in comparable concentrations with those reported by Saify et al., (2003) for the same fatty acids in the liver lipids of marine Eusphyra blochii and Carcharhinus bleekeri. The results of the present investigation are also in line with those described by Kiessting et al. (2001). Even in low concentrations, these polyunsaturated fatty acids are an important group of lipid metabolism and are bases for the formation of arachidonic acid C20:4 (n-6) and eicosapentaenoic acid 20:5 (n-3), precursors for eicosanoic acid and the relative levels of these two fatty acids have profound effect on the formation of very active substances metabolically (Sargent et al., 1995). Polyunsaturated fatty acids (PUFA $\mathrm{n}-6)$ which dominate structural lipids and, like monoenes, are highly affected by factors such as lipid contents, growth levels and body weight. Particularly as precursor fatty acids to eicosanoids and arachidonic acid, PUFA (n-6) are metabolized from adipose tissues (Voss et al., 1991; Sargent et al. 1995; Wouters et al., 2001).

\section{CONCLUSIONS}

From the present study, it is concluded that the liver of both wild and farmed Catla catla fish species is a good source of lipids and important saturated and unsaturated fatty acids. Hence, the liver of Catla catla fish could be used in the human diet or as supplementary food for other animals as it is an excellent source of good quality fatty acids, especially PUFA under higher body weights. The liver of Catla catla from both farmed and wild species can provide a good source of lipids and fatty acids and should be used in different commodities of animal feeds. Therefore, this study is valuable for dieticians.

\section{REFERENCES}

Al-Asgha N A. 1992. Variation in the carcass composition of Oreochromis niloticus in relation to body weight and length. Pak. J. Zool. 24, 47-51.

AOAC (Association of Official Analytical Chemist). 1990. Official methods of analyis $7^{\text {th }}$ ed. (S. Villiams ed.). AOAC, INC, ARLINGTON, VIRGINIA.
Caulton M S, Burselle E. 1977. The relationship between changes in condition and body composition in young Tilapia rendalli. Boulenger. J. Fish. Biol. 11, 143-150.

Craig SR, Mackenzie DS, Jones GG, Delbert M. 2000. Seasonal changes in the reproductive condition and body "compositon of free-renging red drum, Sciaenops ocealltus. Aquaculture 190, 89-102.

Hassan M. 1996. Influence of pond fertilization with broiler dropping on the growth performance and meat quality of major carps. Ph.D. Thesis Univ. Agr. Faisalabad. P. 195

Hussain B. 2002. Total lipds of fatty acid profile of Liver, Gonadsan Muscles, from wild and farmed Labeo rohita. M.Sc. Thesis, University of the Punjab, Lahore. P. 109.

Kiessling A, Pickova J, Johasson L, Asgard T, Storebakken T, Kiessling KH. 2001. Changes in fatty acid composition in muscle and adipose tissue of farmed rainbow trout (Oncorhynchus mykiss) in relation to age. Food Chem. 73, 271-284.

Kromhout DE, Bosscheiter EB, Lezenn CD. 1985. Inverse relation between fish oil consumption and 20 years mortality from coronary heat disease. New Engl. J. Med. 312, 1205 - 1209.

Kumar D. 1992. Fish culture in un-drainable ponds. A manual for extension F.A.O. Fisheries Technical paper. No. 235. Rome: 239.

Love RT, Miyazaikr T, Rabegnator S. 1984. Requirements for alpha - tocopherol by channel cat fish fed diets low in polyunsaturated triglycerides. J. Nutr. 114, 894 $-901$.

Mahboob S. 1992. Influence of fertilizwer and articial feed on the growth performance in composite culture of major common and some Chinese carps. Ph.D. Theis (Deptt. of Zoology and Fisheries), Univ. of Agril., Faisalabad.

Mahboob S, Sheri AN. 1997. Growth performance of major, common and Chinese carps under composite culture system with special reference to pond fertilization. Aqua. Trop. 12, 201-207.

Mahboob S, Kanwal S, Hassan M, Hussain A, Nadeem S. 2003. Fatty acid composition in Muscle, liver and gonad from wild and farmed Cirrhina mrigala. Aquaculture Europe 2003, Trondheim, Norway, 8-12.

Osman H, Suriah AR, EC. 2001. Fatty acid compositon selected marine fish Malaysian waters. Food Chem. 73, 55-60.

Perumal S, Becker K. 2003. Antioxidant properties of various solvent extracts of total phenolic constituents from three agroclimatic origins of Drumstick tree leaves. J. Agri. Food Chem. 51, 2144-2155.

Polvi SM, Ackman RG. 1992. Atlantic salmon (Salmo salar) muscle lipids and their response to alternative dietary fatty acid sources. J. Agri. Food Chem. 40, 1001-1007.

S. A. S. 1995. Statistical Analysis System. SAS Institute, Inc., P.O. Box 8000, Cary, North Carolina, USA.

Sargent JR, Bell J, Bell MVL, Henderson RJ, Tocher DR. 1995. Requirement criteria for essential fatty acids. J. Appl. Ichthyol. 11, 183 - 198.

Saify ZS, Akhtar S, Khan KM, Perveen S, Ayattollahi SAM, Hassan S, Arif M, Haider SM, Ahmad F, Siddiqui S, Khan MZ. 2003. A study on fatty acid composition of fish liver oil from two marine fish, Eusphyra blochii and Carcharhinus bleekeri, Turk. J. Chem. 27, 251-258.

Srikanth GN, Nadeesha MC, Keshavanth P, Varghese TJ, Shetty HPC and Basavaraja N. 1989. On the applicability of mixed feeding schedule of common carp Cyprinus carrpio Ye. Communis. In: E.A. Huismain, 
Zoonneveld, and A.H. Boumans (Eds.). Proceddings of the Asian Seminal on Aquaculture, Malang, Indonesia, 14-18.

Tabassum N. 2003. Fatty acid profile of fish flesh from cyprinus carpio and Hypophthalmichthy moltitrix. M.Sc. Thesis Department of Zoology, GC University, Faisalabad.p. 105.
Voss A, Reinhart M, Sankarappa S, Sprecher H. 1991. The metabolism of $7,10,13,16,19$ dcosahexaenoc acid in rat liver is independent of a 4-desturase. J. Biol. Chem. 266, 195-200.

Recibido: $16 / 3 / 09$ Aceptado: 3/7/09 